\title{
Brief Note on a Set of Constants in a Variable-Compliance-Type Constitutive-Equation
}

by Seisuke OKUBO ${ }^{1}$ and Katsunori FUKUI ${ }^{1}$

1. Graduate School of Engineering, The University of Tokyo, Bunkyo-ku, Tokyo 113

\begin{abstract}
A variable-compliance-type constitutive-equation was formerly proposed by Okubo et al. In this brief note, several ways how to obtain a set of four constants required to solve the equation are described. The constant strain-rate test, comparing with creep, constant stress-rate and relaxation tests, is recommended to be most appropriate for obtaining constants readily and easily. Based on some example sets obtained through experimental works on seven Japanese rocks, the effects of confining pressure and moisture content on the value of each constant are discussed.
\end{abstract}

KEY WORDS : Rock, Visco-elasticity, Time-dependent Behaviour, Confining Pressure, Constitutive Equation

\section{1.はじめに}

筆者は，既報（大久保ほか，1987b）にて，コンプライアンス 可変型構成方程式を提案した。この構成方程式は, 実用の便を図 るため, 含まれる定数の数をできる限り減らしたものである。そ の後, いくつかの岩石に対し, 構成方程式中の定数を求める試み をくり返し行った。その経験に基づいて，本稿では定数の求め方 について解説するとともに, 求められた定数を示し若干の検討を する。その際に注目したのは次の 2 点である。

\section{(1)周圧の影響 \\ (2)水分の影響}

\section{2.一軸応カ下での構成方程式と定数}

著者の提案したコンプライアンス可変型構成方程式は，一軸応 力下では次のようになる（大久保, $1992 \mathrm{a}$ )。

$$
\mathrm{d} \lambda / \mathrm{d} t=a \lambda^{m} \sigma^{n}
$$

$\lambda$ はコンプライアンスで, 歪 $\varepsilon$ を応力 $\sigma$ で除した值 $(\varepsilon / \sigma)$ であ る。 $t$ は時間である。 $n$ は時間依存性の程度を決める定数で, 定 歪速度試験に㧈けるピーク強度の載荷速度依存性や，クリープ試 験における寿命の応力依存性を決定する。 $m$ はピーク強度以降 の応力一歪曲線の傾きを決める定数で, この值が大きいほどピー ク強度以降の応力の低下が急激となる。 $a$ はピーク強度を決める 定数で,この值が大きいほど強度が低下する。

この構成方程式を一軸応力下で解くには， $\lambda$ の初期值 $\lambda_{1}$ と， 構成方程式に含まれる 3 定数 $n, m, a$ の值が必要である。なお,

* 1996 年 10 月 7 日受付 1997 年 5 月 12 日受理

1. 正会員 工博 東京大学教授 工学系研究科地球システム工学専攻

2. 正会員 工博 東京大学助教授 工学系研究科地球システム工学専攻

〔著者連絡先〕FAX 03-3818-7492（東大·地球）E-mail:

キーワード : 岩石, 粘弾性, 時間依存性挙動, 周圧, 構成方程式
各定数の範囲は, 既報（大久保, $1992 \mathrm{a}$ ）と同じく下記のごとく である。

$$
a>0, \infty>m>-\infty, n \geqq 1
$$

$\lambda_{1}$ の求め方についてまず述べる。表 1 に示すように， $\lambda_{1}$ は通常 各試験の途中で得られるピーク強度の $50 \%$ の位置で得られる接 線ヤング率の逆数でよい。岩石によっては, 応力の低いうちから 応力一歪曲線が非線形となるが, このような岩石の変形特性をよ り正確に表すには(1)式の右辺に項を追加する必要がある。本稿 ではそこまで踏み込まないことにする。

$n$ の値は, クリープ試験, 定応力速度試験, 定歪速度試験, 応 力緩和試験のいずれからも求めることができる。クリープ試験で は, クリープ応力 $\sigma_{1}$ と寿命 $t_{c}$ の関係がわかれば, 表 1 に示した 次式より $n$ が計算できる。

$$
n=\frac{\delta\left(\ln t_{c}\right)}{\delta\left(\ln \sigma_{1}\right)}
$$

具体的には, 両対数線図の縦軸と横軸を, それぞれ寿命とクリー プ応力とし, 両者の関係を直線で近似したときの傾きを求めれば よい。適用範囲は, $m>1$ である。 $m \leqq 1$ では, 歪硬化が生じ るのみで破壊が生じないので $t_{c}$ が求められない。破壊せず $t_{c}$ が 求められないときは, 実験より求めたクリープ曲線と計算結果と が一致するよう，計算機を使用して試行錯誤をする必要がある。 以下で述べる他の試験でも, 破壊しないときは, 計算機を使用し た試行錯誤が必要である。

定応力速度試験の場合, 載荷速度 $C$ とピーク強度 $\sigma_{c}$ の関係が わかれば, 表 1 に示した式より $n$ が計算できる。適用範囲は, $m$ $>1$ である。 $m \leqq 1$ では破壊が生じないのでピーク強度 $\sigma_{c}$ が求 められない。定歪速度試験の場合も, 表 1 に示した式より $n$ を 計算できる。適用範囲は， $m>0$ である。 $m \leqq 0$ では破壊が生 じないのでピーク強度 $\sigma_{c}$ が求められない。応力緩和試験の場合 には, $m$ が $(n+1)$ より大きい場合, 表 1 に示した式から $n$ を 
表 1 構成方程式の定数の求め方

\begin{tabular}{|c|c|c|c|c|}
\hline $\begin{array}{c}\text { Constitutive } \\
\text { Equation }\end{array}$ & & $\frac{d \lambda}{d t}=a \lambda^{m} \sigma^{n} \quad \lambda=\frac{\varepsilon}{\sigma}$ & $a>0,+\infty>m>-\infty, n \geq 1$ & \\
\hline $\begin{array}{c}\text { Test } \\
\text { (Condition) } \\
\text { Initial Condition }\end{array}$ & $\begin{array}{c}\text { Creep } \\
\left(\sigma=\sigma_{1}\right) \\
\varepsilon=\varepsilon_{1}=\lambda_{1} \sigma_{1}\end{array}$ & $\begin{array}{c}\text { Constant Stress Rate } \\
(\dot{\sigma}=c) \\
\lambda=\lambda_{1}, \sigma=0\end{array}$ & $\begin{array}{c}\text { Constant Strain Rate } \\
\begin{array}{c}(\dot{\varepsilon}=c) \\
\lambda=\lambda_{1}, \varepsilon=0\end{array}\end{array}$ & $\begin{array}{c}\text { Relaxation } \\
\left(\varepsilon=\varepsilon_{1}\right) \\
\sigma=\sigma_{1}=\varepsilon_{1} / \lambda_{1}\end{array}$ \\
\hline$\lambda_{1}$ & \multicolumn{4}{|c|}{ inverse of $50 \%$ tangential Young's modulus } \\
\hline$n$ & $\begin{array}{l}m>0 \\
\frac{\delta\left(\ln t_{c}\right)}{\delta\left(\ln \sigma_{1}\right)}\end{array}$ & $\begin{array}{l}m>1 \\
\frac{\delta(\ln c)}{\delta\left(\ln \sigma_{c}\right)}-1\end{array}$ & $\begin{array}{l}m>0, m \neq n+1 \\
\frac{\delta(\ln c)}{\delta\left(\ln \sigma_{c}\right)}-1\end{array}$ & $\begin{array}{l}m>n+1 \\
\frac{\delta\left(\ln t_{c}\right)}{\delta\left(\ln \sigma_{1}\right)}\end{array}$ \\
\hline$m$ & \multicolumn{2}{|c|}{ not feasible } & refer to Fig.1 & not feasible \\
\hline$a$ & $\begin{array}{l}m>1 \\
\frac{1}{m-1} \lambda_{1}^{1-m} \cdot \sigma_{1}^{-n} \cdot t_{c}^{-1}\end{array}$ & $\begin{array}{l}m>1 \\
\left(\frac{n+1}{m-1}\right) \lambda_{1}^{1-m} \cdot \sigma_{c}^{-(n+1)} \cdot c\end{array}$ & $\begin{array}{l}m>0, m \neq n+1 \\
\left(\frac{m}{n+1}\right)^{\frac{m}{n-m+1}} \lambda_{1}^{-m} \cdot \sigma_{c}^{-(n+1)} \cdot c\end{array}$ & $\begin{array}{l}m>n+1 \\
\frac{1}{m-n-1} \lambda_{1}^{1-m} \cdot \sigma_{1}^{-n} \cdot t_{c}^{-1}\end{array}$ \\
\hline
\end{tabular}

$\sigma_{c}:$ peak strength, $t_{c}:$ life time, $\delta\left(\ln t_{c}\right):$ finite difference of $\left(\ln t_{c}\right)$

求めることができる。 $m$ が $(n+1)$ より小さいと, 試験片の破 壊が生じない。試験開始より破壊するまでの時間 $t_{c}$ は, 応力緩 和を開始した応力 $\sigma_{1}$ に依存するので, この関係を利用して $n$ を 求めることができる。

$m$ は, 定歪速度試験より求める。原理的には他の試験からも 求まるはずであるが実際は困難である。定歪速度試験の場合, $m$ はピーク強度以降の応力ー歪曲線の傾きと関係がある。 $m$ を求 めるため, 実験結果と計算結果とが一致するまで, 計算機を使用 したくり返し計算を行うことが考えられるが, やや面倒である。 簡便に $m$ を求める方法を図 1 のように提案する。ここで, $\mathrm{A}$ 点 は, ピーク強度の $50 \%$ の位置 B 点における接線と, 応力をピー ク強度に保った直線との交点である。C 点は, 線分 $\mathrm{AB}$ と $\mathrm{AC}$ の 長さが等しくなるように決めた。水平な直線 $\left(\sigma=\sigma_{c}\right)$ より右回 りに測った角度 $\alpha^{\prime}$ を図のように求め, $\alpha=\arctan \left(\tan \alpha^{\prime} / \tan \theta\right)$ を計算する。当然ながら, 50 \% 接線の傾き $\theta$ を $45^{\circ}$ とした場合

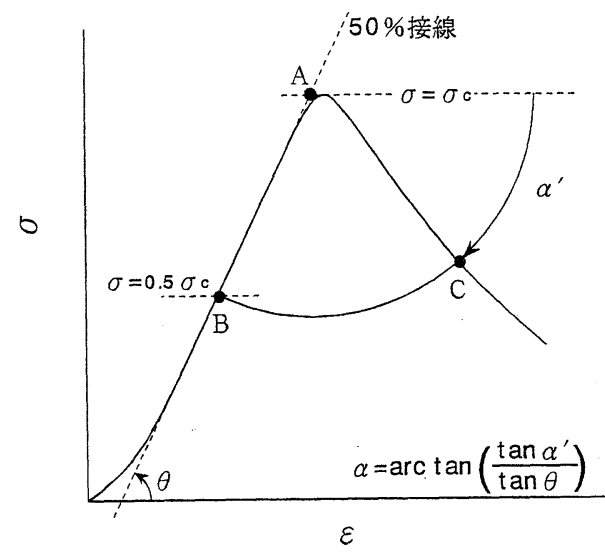

手順 1） $50 \%$ 接線と、 $\sigma=\sigma c$ との交点Aを求める。

2) $\mathrm{A}$ 点を中心として、半径㓱の円弧を描き、 交点Cを求める。

3 ) 直線 $\mathrm{AC} 、 \sigma=\sigma \mathrm{c}$ とのなす角を $\alpha^{\prime}$ とする。

4) $\alpha=\arctan \left(\frac{\tan \alpha^{\prime}}{\tan \theta}\right)$ を計算する。

図 1 ピーク強度以降の応力一歪曲線の傾きの 代表值 $\alpha$ の求め方
には， $\alpha$ と $\alpha$ は一致する。こうして求めた $\alpha$ と, $m / n$ の関係を 図 2 に示す。なお， $\alpha$ が負の值となるのは，ピーク強度を示さず, 応力一歪曲線が右上がりに上昇していく場合である。

各試験で得られた結果（例えば定歪速度試験では載荷速度 $C$ とピーク強度 $\left.\sigma_{c}\right)$ と, $\lambda_{1}, n, m$ の值を, 表 1 に示した式に代 入すると $a$ の值が計算できる。

以上では簡単のため一軸圧縮応力下での構成方程式について述 べたが, $\lambda_{1}, a, m, n$ の求め方は, 周圧下でもほとんど変わら ない。これまでの歪 $\varepsilon$ と応力 $\sigma$ を, 周圧相当分を差し引いた差歪, 差応力として扱うだけである。

\section{3. いくつかの岩石における定数の值}

\section{$3 \cdot 1$ 周圧の影響}

表 2 に検討した岩石と諸值を記す。差応力で表したピーク強度 (最大主応力差) および $\lambda_{1}$ は, 定歪速度試験より求めた。表中の $n$ の值は, 歪速度を何段階かに変えて定歪速度試験を行い, 表 1 に示した式より計算した。なお，一部の岩石では,クリープ試験 の結果からも $n$ を求めたが, 定歪速度試験より求めた值と大差 なかった。 $\alpha$ は図 1 に示した方法で求めた。構成方程式中の $a$

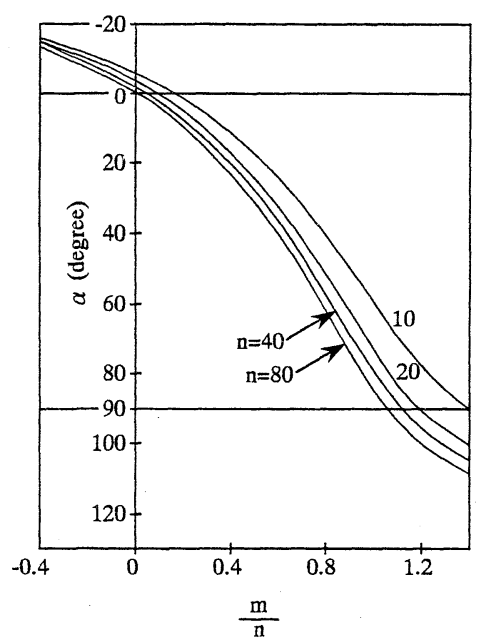

図 $2 \alpha$ と $m / n$ の間の関係 
表 2 検討した岩石の諸值

\begin{tabular}{|c|c|c|c|c|c|c|}
\hline 岩石 & 実験条件 & $\begin{array}{c}\text { 最大主忘力差 } \\
(\mathrm{MPa}) \\
\end{array}$ & $\begin{array}{c}\lambda_{1} \\
(1 / \mathrm{GPa}) \\
\end{array}$ & $\mathrm{n}$ & $(\alpha)$ & 出典 \\
\hline 稲田花崗岩 & $\begin{array}{r}\text { 一軸圧縮(気乾) } \\
\Rightarrow \quad \text { (湿潤) } \\
\text { 三軸圧縮(気乾) } \\
\text { 周圧 } 5 \mathrm{MPa} \\
10 \mathrm{MPa} \\
20 \mathrm{MPa} \\
40 \mathrm{MPa}\end{array}$ & $\begin{array}{l}193 \\
185 \\
\\
274 \\
348 \\
422 \\
556 \\
\end{array}$ & $\begin{array}{l}1 / 37.6 \\
1 / 37.6 \\
\\
1 / 39.7 \\
1 / 39.7 \\
1 / 40.4 \\
1 / 40.4 \\
\end{array}$ & $\begin{array}{c}51 \\
38 \\
\\
\\
72 \\
92 \\
112 \\
147\end{array}$ & $\begin{array}{l}99 \\
99 \\
62 \\
56 \\
42 \\
38\end{array}$ & $\begin{array}{l}\text { 何(1989a) } \\
\text { 何ほか(1989b) } \\
\text { Okubo ほか(1990) }\end{array}$ \\
\hline 三城目安山岩 & $\begin{array}{r}\text { 一軸圧縮(気乾) } \\
\| 1 \text { (湿潤) } \\
\text { 三軸圧縮(気乾) } \\
\text { 周圧 } 5 \mathrm{MPa} \\
10 \mathrm{MPa} \\
20 \mathrm{MPa} \\
40 \mathrm{MPa}\end{array}$ & $\begin{array}{l}93.9 \\
73.4 \\
\\
141 \\
167 \\
207 \\
244 \\
\end{array}$ & $\begin{array}{l}1 / 9.3 \\
1 / 8.4 \\
1 / 13.7 \\
1 / 14.2 \\
1 / 14.2 \\
1 / 14.5 \\
\end{array}$ & $\begin{array}{l}37 \\
28 \\
\\
48 \\
56 \\
70 \\
83 \\
\end{array}$ & $\begin{array}{l}91 \\
88 \\
66 \\
48 \\
27 \\
17 \\
\end{array}$ & $\begin{array}{l}\text { 何ほか(1989b) } \\
\text { Okubo ほか(1990) } \\
\text { 大久保ほか(1992b) }\end{array}$ \\
\hline 河津凝灰岩 & 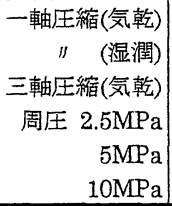 & $\begin{array}{l}33.3 \\
22.3 \\
\\
36.0 \\
37.7 \\
39.5 \\
\end{array}$ & $\begin{array}{c}1 / 6.3 \\
1 / 5.2 \\
1 / 6.4 \\
106.4 \\
1 / 6.4 \\
\end{array}$ & $\begin{array}{l}57 \\
37 \\
\\
62 \\
64 \\
67 \\
67\end{array}$ & $\begin{array}{l}68 \\
74 \\
9 \\
9 \\
3 \\
0 \\
\end{array}$ & $\begin{array}{l}\text { 何(1989a) } \\
\text { 何ほか子(1989b) } \\
\text { Okubo ほか (1990) }\end{array}$ \\
\hline 大谷凝灰岩 & $\begin{array}{r}\text { 一軸圧縮(気乾) } \\
\| \prime \quad \text { (湿潤) }\end{array}$ & $\begin{array}{l}12.2 \\
5.63\end{array}$ & $\begin{array}{l}1 / 2.7 \\
1 / 1.3\end{array}$ & $\begin{array}{l}35 \\
16\end{array}$ & $\begin{array}{l}32 \\
31\end{array}$ & 大久保ほか $(1992 b)$ \\
\hline 由下㠜灰岩 & 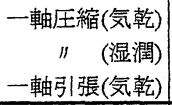 & $\begin{array}{l}16.8 \\
9.74 \\
1.87 \\
\end{array}$ & $\begin{array}{l}1 / 3.6 \\
1 / 2.5 \\
1 / 2.8 \\
\end{array}$ & $\begin{array}{l}42 \\
23 \\
42 \\
\end{array}$ & $\begin{array}{l}20 \\
34 \\
19 \\
\end{array}$ & 秋(1995) \\
\hline 秋吉大理石 & 一軸圧縮(気、乾) & 124 & $1 / 35.1$ & 63 & 38 & $\begin{array}{l}\text { 大久保ほか(1987a) } \\
\text { 何(1989a),Okubo ほか(1990) }\end{array}$ \\
\hline 和泉砂岩 & 一軸圧縮(気乾) & 214 & $1 / 25.0$ & 61 & 102 & ibid. \\
\hline
\end{tabular}

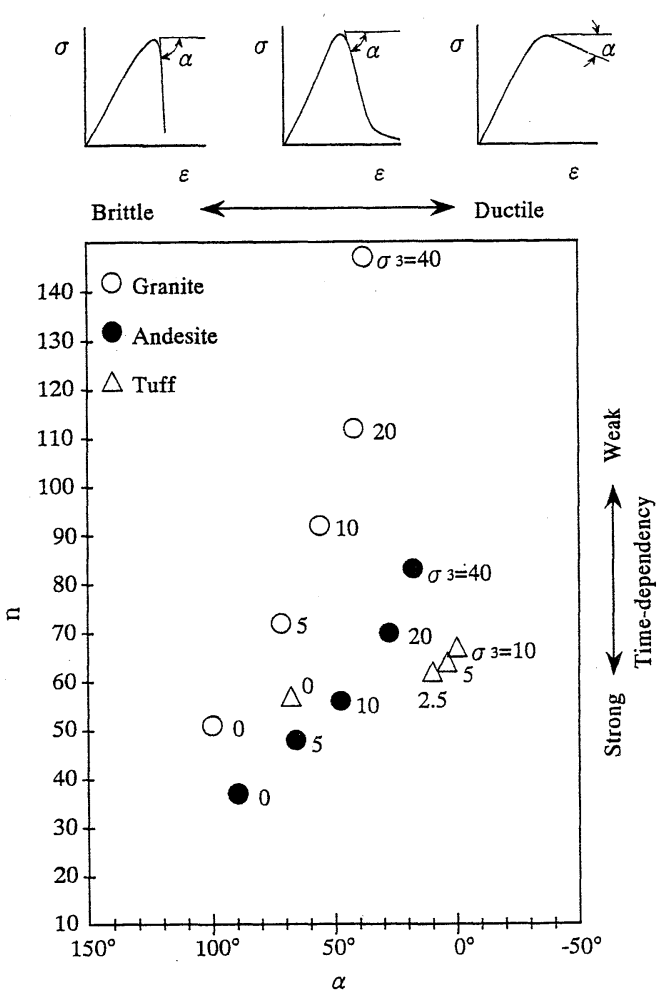

図 3 時間依存性の指標 $n$ と延性・ぜい性の指標 $\alpha$ の関係 (周压 $\sigma_{3}$ の影響)

$\bigcirc$ : 稲田花崗岩 $\bigcirc$ :三城目安山岩 $\triangle$ : 河津㠜灰岩

と $m$ は, それぞれ表 1 中の式, 図 2 を利用して簡単に求まるの で割愛した。

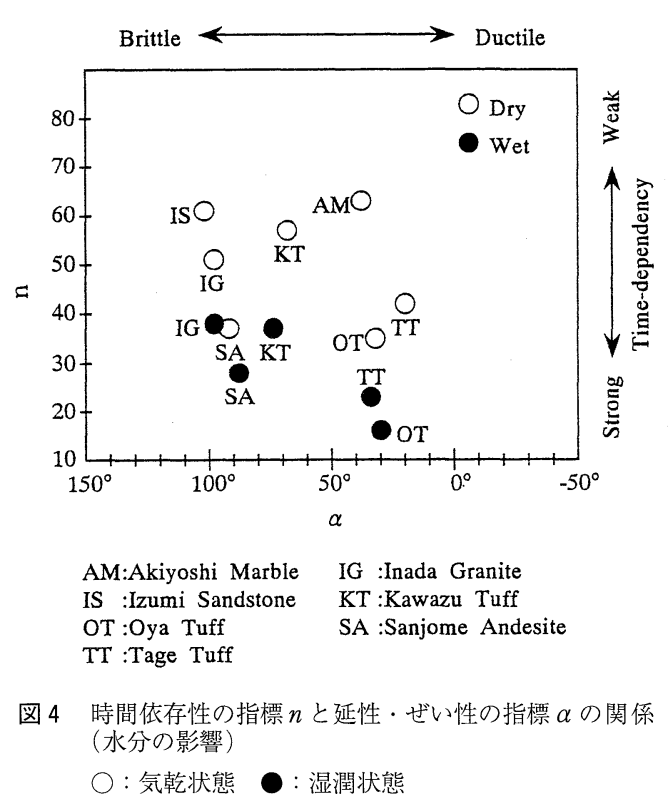

図 3 は, 縦軸を $n$ とし, 横軸を $\alpha$ とし, 周圧 $\sigma_{3}$ により位置が どのように変化するかを示したものである。なお，nの值が大き いほど, 時間依存性は弱くなる。例えば, 定歪速度試験における ピーク強度載荷速度依存性が小さくなり, 次第に塑性的な振る舞 いに近づく。また， $\alpha$ が小さいほど，ピーク強度以降の応力の低 下が緩やかになり, 延性的な挙動を示す。なお, 横軸として $m$ ないし $m / n$ をとることも考えたが， $\alpha$ の方が直裁的でわかり易 いと思ったので横軸にとった。

まず，○で表した稲田花崗岩の結果を検討する。大気圧下での 
試験より，周圧が $5 ， 10 ， 20 ， 40 \mathrm{MPa}$ と大きくなるに従って， 延性的になるとともに時間依存性が顕著に隇少する。周圧の増加 により延性的となることはよく知られているが, 時間依存性に関 する報告は少ない。゙城目安山岩の結果を示す。花崗岩と比 較して, 周圧による $n$ の值の変化はやや少ないが, $\alpha$ の值の変 化は大きい。வで河津凝死岩の結果を示す。この場合には，nの 変化は少ないのに対し， $\alpha$ はかなり変化する。

\section{$3 \cdot 2$ 水分の影響}

鋼材をはじめとする工業材料においても, まわりの環境, 特に 水分の有無により腐蝕の進行が大いに異なることが知られている。 しかし，多くの場合，材料内部への水の浸透は極めて微小であり， 表面近傍の変化のみを議論すれば事足りる。他方, 多くの岩石で は, 水分が内部まで浸透するので, 水の有無によって, 力学的性 質が大きく左右される。

図 4 に, 一軸圧縮応力下で行った定歪速度試験の結果をまとめ てみた。○で気乾状態での結果を, ○で完全湿潤状態での結果を 示す。これよりわかるように, 多少のばらつきはあるものの, 気 乾状態の結果の下方に湿潤状態の結果が位置する傾向がみられる。

\section{4. を め}

コンプライアンス可変型構成方程式を解くのに必要な定数の求 め方を表 1 に示した。多くの場合, 定歪速度試験より諸值を求め るのが最も簡単である。その際計測すべきデー夕は, 応力と歪で ある。定数を求める順序は， $\lambda_{1}, n, m, a$ である。まず $50 \%$ 接線ヤング率の逆数として $\lambda_{1}$ を求める。次に載荷速度を変えた 時のピーク強度の変化より $n$ を求める。ついで, 図 1 に示した ように $\alpha$ を求め $m / n$ の值を得る。最後に, $\lambda_{1}, n, m$, 載荷速 度 $C$, ピーク強度 $\sigma_{c}$ より $a$ を計算する。

いくつかの岩石の試験結果より定数を求め表 2 に示した。図 3 ～ 5 に示すように, 縦軸を $n$ (時間依存性の指標), 横軸を $\alpha$ （延性・ぜい性の指標）として, 周圧の影響, 水分の影響を検討 してみた。その結果次の傾向がみられた。(1)周圧の増加ととも に図上の位置が右上方に移動する。(2)水分があると位置が下方 に移動する。

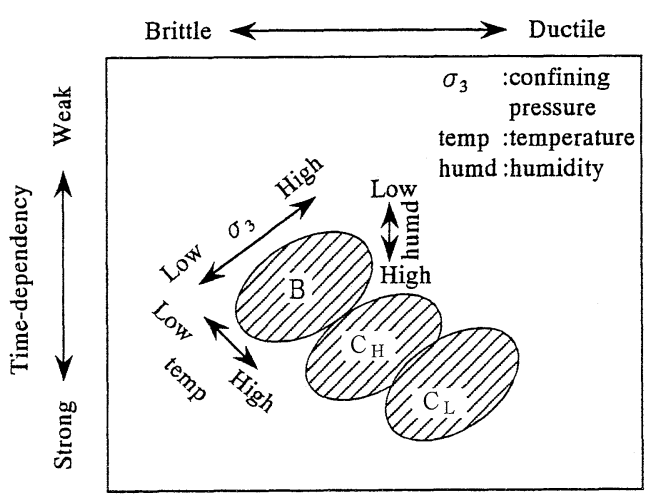

図 5 岩石・岩盤における $n$ と $\alpha$ の関係の仮説の例で次の 4 つ の仮定を置いて描いた。(1)周圧の増加とともに図上の位 置が右上方に移動する。(2)水分があると位置が下方に移 動する。(3)温度が高いと, 右下方に移動する。(4) 強度 が弱いと, 右下方に移動する。なお, $\mathrm{B}, \mathrm{C}_{\mathrm{H}}, \mathrm{C}_{\mathrm{L}}$ は電力 中央研究所の方式にならった岩盤分類である。

今後の研究目標として考えている仮説の一例を図 5 に示す。こ の図を描くのに以下の 2 つ仮定を加えた。(3)温度が高いと, 時間依存性が増し，延性的な性質を示す。(4)弱い岩石・岩盤ほ ど，時間依存性が増し，延性的な性質を示す。なお， B, $\mathrm{C}_{\mathrm{H}}, \mathrm{C}_{\mathrm{L}}$ は電力中央研究所の方式にならった岩盤分類である。このよう な仮説を念頭に打いて, 室内試験, 原位置試験, 計算機シミュレー ションを併せて行い, 真実の姿がどの仮説に近いかを今後検討す る予定である。

\section{引用文 献}

秋晳淵（1995）：岩石の湿沺状態に扔计万時間依存性, 東京大学博士論文 何昌栄 (1989 a) : 岩石の压縮荷重下での変形・破壊の時間依存性, 東京大学博士論文 何昌栄·大久保誠介・西松裕一 $(1989$ b) : 材料, Vol. 38, p. 216-220 大久保誠介・何昌栄・西松裕一 (1987 a) : 日本釷業会誌, Vol. 103, p. 177-181 大久保誠介・西松裕一・緒方義弘 (1987 b) : 日本釯業会誌, Vol. 103, p. 293-296 Okubo, S., Nishimatsu, Y. and He, C. (1990) : Int. J. Rock Mech. Min. Sci. \& Geomech. Abstr., Vol. 27, No. 6, p. 559-562 大久保誠介 (1992 a)：資源と素材, Vol. 108, p. 601-606 大久保誠介・西松裕一・何昌栄·秋梠淵 (1992 b) : 材料, Vol. 41, p. 403-409 